Vladimir S. Mentus ${ }^{1}$

Institute of Social Sciences

Belgrade (Serbia)
UDC 316.644:613.86

(497.11)"2011/2016"

Original scientific paper

Submitted 25/10/2019

Revised 03/01/2020

Accepted 23/02/2020

doi: 10.5937/socpreg54-23748

\title{
DETERMINANTS OF MENTAL WELL-BEING IN SERBIA²
}

Abstract: In this paper we examined the determinants of mental well-being in Serbia. Mental well-being is defined as a state of well-being in which the individual realizes his or her own potential, can cope with the normal stresses of life, can work productively and fruitfully, and is able to make a contribution to his or her community. Although the studies from this field on nationally representative samples from other countries are widely present, they are entirely neglected in Serbia. We used nationally representative Serbian samples from 2011 and 2016 that come from the European Quality of Life Survey. The data indicate that mental well-being declines with age, especially among older woman categories. Second, subjective general health is the most significant determinant of mental well-being. Optimism about own future, feeling tense, and satisfaction with family life come next. We also examined trends of mental well-being in five-years between the two rounds of the survey and found its slight but statistically non-significant decline.

Keywords: Mental well-being, Serbia, European Quality of Life Survey, WHO-5 scale

\section{Introduction}

In this paper we examined the determinants of mental well-being among the population of Serbia. The World Health Organization (WHO, 2004) defines mental health (which is most often used in literature interchangeably with mental well-being) as a state of well-being in which the individual realizes his or her own potential, can cope with the normal stresses of life, can work productively and fruitfully, and is able to make a contribution to his or her community. Another important aspect of mental health is the capacity for mutually satisfying and enduring relationships (Tennant et al., 2007).

The field of positive mental health is relatively complex, covering both affects and psychological functioning with two distinct perspectives: on one side, there is a hedonic perspective, which focuses on the subjective experiences of life satisfaction and happiness,

\footnotetext{
1 vmentus@idn.org.rs

2 The paper is the result of the project "Structural, Social and Historical Changes of Serbian Society in the Context of European Integration and Globalization" (OI 179039) funded by the Ministry of Education, Science and Technological Development of the Republic of Serbia.
} 
and, on the other side, there is a eudaimonic perspective, based on psychological functioning and self-realization (Tennant et al., 2007). Empirical evidence has indicated that absence of a mental disorder does not equal the presence of mental health, as the findings show the independence of positive and negative health; also, as positive mental well-being contributes to the social, human, and economic capital, its promotion is essential in its own right (Barry, 2013).

Although the studies from this field on nationally representative samples from other countries are widely present, they are entirely neglected in Serbia ${ }^{3}$. The last decades have been very painful for the majority of the population in Serbia, namely, since the 1990s, there have been wars and the immigration of hundreds of thousands of refugees, economic sanctions, huge hyperinflation, NATO aggression, and thus, dramatic impoverishment and economic collapse, deterioration of the healthcare system, etc. Today the country is characterized by a de-industrialized economy, an extremely low level of economic activity, a high rate of unemployment and emigration, especially of young people, the growth of social inequalities and conflicts, etc. (UNICEF Serbia, 2019; Novaković, 2017; Dušanić, 2017; 2018). All of these should have substantial adverse effects on the mental well-being of the population in Serbia.

More importantly, we expect the primary effect of non-material well-being domains on mental well-being. More concretely, most frequently used mental well-being measures, such as WEMWBS (Tennant et al., 2007), WHO-5 (Topp et al. 2015), PHQ-9 (Kroenke et al., 2001), GHQ (Goldberg et al., 1979), or CES-D (Radloff, 1977), mainly consist of affective well-being items, which are shown to be more related to non-material well-being indicators (Kahneman and Krueger, 2010; Kahneman and Krueger, 2006). Also, as already shown on a nationally representative sample from Serbia (Vladisavljević and Mentus, 2019), affective well-being is positively related to many well-being indicators and, compared to the material ones, it is more related to non-material indicators such as perceived health, personal security, and social connections.

\section{Prior research}

There are numerous studies from other countries that examine determinants of mental well-being. In this part, we briefly present the most important findings from these studies, which indicate the expected relations of relevant determinants with mental well-being.

- Demographic determinants - The prevalence of mental disorders such as anxiety and depression, and mood disorders is higher among females (Klose and Jacobi, 2004), but when it comes to overall mental well-being, the relation is not so clear. Some studies indicate higher scores for men (Stephens et al., 1999), some for women (Huppert et al., 1989; Ryff and Singer, 1998), while many studies indicate no substantial gender differences (Diener, 2009; Helliwell, 2003; Donovan and Halpern, 2002).

The relation between age and mental well-being is not so clear either. Most surveys indicate a $U$-shaped relation between various mental well-being indicators

3 Although there are some useful reports based on nationally representative data sets (IZJZS „Batut”, 2008; Boričić et al., 2014; Knežević et al., 2009). 
and age in many countries (Blanchflower and Oswald, 2008; Clark and Oswald, 1994; Singleton et al., 2001), and also a negative relation (Ferrer-i-Carbonell and Gowdy, 2007), while some show no relation (McKee-Ryan et al., 2005). ${ }^{4}$

Although the direction of causation is not clear, many studies indicate a positive relation between marriage and mental well being (Waite and Gallagher, 2000; Lamb et al., 2003; Simon, 2002; Horwitz et al., 1996; Kim and McKenry, 2002). Some studies show that only getting married, but not being married, has positive effects on mental well-being (Zimmermann and Easterlin, 2006). On the other side, marital dissolution is evidenced to affect mental well-being negatively (Mastekaasa, 1994).

- Socioeconomic determinants - Education is most often positive related to mental well-being (Dolan et al., 2008). However, some studies indicate that the risk of reporting psychological distress is higher among those with higher educational levels (Fagg et al., 2008). Also, job-related stress of occupations requiring a degree and the role of education in unfulfilled expectations may be related to depression (Chevalier and Feinstein, 2006).

Unemployment is often associated with poorer mental well-being in the cross-sectional studies (Fagg et al., 2008; Evans and Repper, 2000) as well as in longitudinal ones (Lucas et al., 2004). ${ }^{5}$ Higher socioeconomic status is indicated in many instances to be positively associated with physical and also mental health (Marmot et al., 2012; Quinlan and Bohle, 2009). Risk of depression and anxiety is shown to be related to lower economic status not only in developing (Weaver and Hadley 2009; Lund et al., 2010; Whiteford et al., 2013) but also in high-income countries (Santana et al., 2015; Lund et al., 2010; Fryers et al. 2005).

- Other determinants - There is an evident pattern of a positive association between physical and mental health (Nabi et al., 2008; Surtees et al., 2008; Pressman and Cohen, 2006) even after controlling for confounders (Ohrnberger et al., 2017). Family life could be essential for mental well-being, as prior research indicates importance of social and emotional support in this sense (Almedom, 2005; De Silva et al., 2005; Harrison et al., 1999; Wu et al., 2003; Cairney et al., 2003; Pevalin et al., 2003). Furthermore, extensive meta-analysis studies show that religiosity has a positive effect on happiness, emotion regulation, positive well-being and mental calmness (Koenig et al., 2012; Tay et al., 2014; Vishkin et al., 2014). On the other side, some studies have found very weak or non-significant associations between religiosity and well-being (Snoep, 2008; Lewis et al., 2005; Lewis, 2002; Lewis et al., 2000).

Living in a rural environment is often related to socioeconomic disadvantages, exposure and vulnerability to environmental adversity, weaker community infrastructure, more reduced access to health and social services, and also geographic isolation (Inder et al., 2017). On the other side, long-term social difficulties, increased crime rate, social isolation, reduced social support, poverty, high levels of

4 Also, interactions between age and gender have also been found (Huppert and Whittington, 2003).

${ }^{5}$ For evidence about contextual factors that influence the relationship between unemployment and mental well-being, see Clark, 2003; Shields and Wheatley Price, 2005; Huppert and Whittington, 2003. 
violence and accidents, insecure tenure and poor housing (all of which are often associated with living in an urban environment) are all positively related to depression (McKenzie, 2008).

Positive and negative expectations regarding the future are essential for understanding the vulnerability to mental disorders, in particular, mood and anxiety disorders (Conversano et al., 2010). Optimism is positively related to self-esteem, low negative emotions, positive affect, and life satisfaction (Ho et al., 2010). It is also negatively related to depressive and anxiety disorders and suicidal ideation. Optimism may significantly influence mental well-being by the promotion of a healthy lifestyle as well as by adaptive behaviours and cognitive responses associated with greater flexibility, problem-solving capacity and a more efficient elaboration of negative information (Conversano et al., 2010).

\section{Method}

The data for the present study came from the European Quality of Life Survey (EQLS). It is a face-to-face survey of the adult population (18+) living in private households, which collects data on current life conditions of respondents across many European countries every four to five years, as well as their attitudes to a wide range of related topics. These include employment, income, education, housing, family, health, work-life balance, life satisfaction, societal quality, etc. Also, a significant number of questionnaire items are replicated from wave to wave, permitting trend analyses in the cross-sectional datasets (Eurofound, 2018).

To the present, nationally representative data from Serbia were collected within the EQLS in 2011 and 2016. The sample sizes are 1002 for 2011 (52\% females, $M_{\text {age }}=47.93$, $\left.S D_{\text {age }}=17.78\right)$ and 1056 for 2016 (51.9\% females, $\left.M_{\text {age }}=48.79, S D_{\text {age }}=17.38\right)$. Our merged sample thus consists of 2058 participants ( $51.9 \%$ females, $\left.M_{\text {age }}=48.37, S D_{\text {age }}=17.58\right)$. We used divided samples only for performing the trend analysis.

We selected twenty-one variables that are recognized as relevant determinants of mental well-being in prior research Table 1. Along with socio-demographic variables such as gender, age, employment and marital status, education level and size of locality, these are: subjective health, satisfaction with family life, satisfaction with the standard of living, ability to make ends meet, being optimistic about own future, feeling worthwhile, feeling free to decide how to live, having time to do the really enjoyable things, feeling particularly tense (over the last two weeks), feeling lonely (over the last two weeks), feeling downhearted and depressed (over the last two weeks), taking part in sports or physical exercise, attending religious services (apart from weddings, funerals or christenings) and social exclusion (consisting of four items: feeling of being left out of the society, feeling of complicated life, feeling of not being recognised by others, and being looked down on by some people because of the job situation or income.

Mental well-being is measured on the WHO-5 scale (Table 1). The score is calculated within EQLS first by recoding response values 0 to 5 . Then the raw score is calculated by totalling the values of the five answers. The raw score ranges from 0 to 25 . To obtain a percentage score ranging from 0 to 100 , the raw score is multiplied by 4 . A percentage score of 0 represents the worst possible, whereas a score of 100 represents the best possible mental well-being (Topp et al. 2015). 
Based on a review of 213 articles, WHO-5 is among the most widely used questionnaires assessing subjective psychological well-being (Topp et al. 2015). Also, since its first publication in 1998, it has been translated into more than thirty languages and has been used in research studies all over the world. The scale has adequate validity both as a screening tool for depression and as an outcome measure in clinical trials, and has been applied successfully across a wide range of study fields. In our Serbian sample, WHO-5 shows a high level of internal consistency $(\alpha=.88)$. The results are, to a great extent, presented by the model in Capone et al., 2019.

\section{Results}

As Figure 1 shows, mental well-being declines with age, with slightly lower WHO-5 scores among woman, except around sixties, and until old age, when woman have significantly lower mental well-being scores $[t(84.426)=3.072, p<.01,95 \%$ CI of difference: $4.373,20.421$, Cohen's $d=0.59]$. Overall, $t$-test shows that women have significantly lower scores of mental well-being $[t(1,987.494)=3.073, p<.01,95 \%$ CI of difference: $1.075,4.869]$ but with a very small effect size (Cohen's $d=0.014$ ).

As affective well-being is one of the key components of general mental well-being, we also examined gender differences in three negative affects (feeling particularly tense, feeling lonely, and feeling downhearted and depressed). T-test indicated a higher negative affect among female participants, but here small effect sizes were found as well (Cohen's $d$ $=0.03, M_{\text {females }}=4.26, S D_{\text {females }}=1.243, M_{\text {males }}=4.41, S D_{\text {males }}=1.227$, for feeling particularly tense; Cohen's $d=0.10, M_{\text {females }}=4.70, S D_{\text {females }}=1.381, M_{\text {males }}=5.03, S D_{\text {males }}=1.230$ for feeling lonely; Cohen's $d=0.12, M_{\text {females }}=4.59, S D_{\text {females }}=1.36, M_{\text {males }}=4.91, S D_{\text {males }}=1.249$ for feeling downhearted and depressed).

We conducted five separate ANOVAs, using other relevant variables as factors explaining mental well-being. The ability to make ends meet, explaining $13.1 \%$ of the variance, was the most significant determinant of mental well-being. Employment status (explaining $8 \%$ of the variance), marital status (explaining $7.7 \%$ of the variance), and education (explaining $6.6 \%$ of the variance) follow (Table 2.

As also shown in Table 2 those with difficulties in making ends meet, unemployed for more than twelve months, and those unable to work due to illness or disability, as well as the divorced and widowed ones, have lower mental well-being scores than other groups. Moreover, mental well-being rises with education level. Finally, location is not a significant determinant of mental well-being.

We also found a statistically significant interaction between age and the ability to make ends meet on mental well-being, $F(30,1969)=2.523, p<.001, \eta^{2}=0.037$. Overall ANOVA shows that five variables collectively explain about $33.3 \%$ of the variance in mental well-being. Unique contributions of the variables decrease when entered alongside each other: $5.1 \%$ for ability to make ends meet, $1.2 \%$ for employment status, $0.6 \%$ for marital status $0.4 \%$ for education, and $0 \%$ for location.

Multiple regression analyses with respective enter and stepwise methods were carried out. We used 21 independent variables and a total sample of 936 participants (that had no missing values on all of them). The results obtained by using the enter method are shown Table 3 
Our selected independent variables collectively explained about $48 \%$ of the variance in mental well-being, $F(21,914)=40.236, p<.001, R^{2}=.480$. Nine out of 21 variables in this model were not significant determinants of mental well-being at the .05 level. The stepwise regression analysis indicated that subjective health was the strongest one, explaining about $28.8 \%$ of the variance. The second strongest was optimism about own future, contributing an additional $7.2 \%$. Feeling tense (3.9\%), satisfaction with family life (1.8\%), taking part in sports or physical exercise (1.8\%) and social exclusion (1.2\%) come next. Feeling free to decide how to live, education level, subjective urbanisation, unemployed status, satisfaction with the standard of living, and attending religious services (apart from weddings, funerals, or christenings) collectively added about $2.7 \%$ of the variance. The stepwise regression analysis also showed that gender, age, feeling worthwhile, having time to do really enjoyable things, feeling lonely, feeling downhearted and depressed, being unable to work due to illness or disability, being divorced, and being widowed were not significant in this model and were therefore excluded.

Tables 4 and 5 show the results of regression analyses across age and gender groups using the enter method, while Table 5 also contains the most important determinants for each group based on the stepwise method. Here, four age categories represent emerging adulthood (15-25 years), young adulthood (26-44), middle adulthood (45-64), and late adulthood (65 years and older) (Capone et al., 2019). The results indicate some differences in the regression coefficients and the most important determinants of mental well-being across the age and gender groups. Subjective health is the most important determinant among both genders and becomes more crucial as age increases. Satisfaction with family life also has a stronger effect among older age categories, while satisfaction with the standard of living has a progressively weaker effect with increasing age.

We also analyzed mental well-being trends between the two waves of EQLS, splitting our merged sample by wave. A $T$-test indicated slight although not significant decline in mental well-being during those five years $(p>0.05)$. Decline is to some extent evident in "My daily life has been filled with things that interest me" item (Cohen's $d=-0.19$, $M_{2016}=3.46, M_{2011}=3.22, S D_{2016}=1.21, S D_{2011}=1.30$ ).

\section{Summary of the results and conclusions}

Using nationally representative data from the European Quality of Life Survey from 2011 and 2016, we examined determinants of mental well-being within the population of Serbia. The results indicated that mental well-being declines with age and also lower scores among women in the oldest age categories. The lack of a U-shaped association between age and mental well-being, which is found in much previous research, suggests that older people cope with mentioned difficult circumstances relatively harder, especially in comparison to older people from other (mainly richer) countries. This is specifically true for women in Serbia and may be explained by the evidence that the importance of health as an essential determinant of mental well-being in general, and an indicator on which women generally have lower scores - is particularly prominent in the old age. Subjective health is once again shown to be the most significant determinant of mental well-being, as in many other countries. The second most significant determinant was optimism about own future, followed by feeling tense and satisfaction with family life. The essential 
effects of optimism, negative affect in general, and family life satisfaction, are also indicated in much previous research.

Furthermore, as also expected, the results generally showed the importance of non-material domains of life for mental well-being in Serbia. The explanation for this may be found in the fact that the WHO-5 scale, as well as other most frequently used mental well-being measures, consists of affective well-being items, which are shown to be more related to non-material well-being indicators. This finding is also consistent with the previous one found on a nationally representative sample from Serbia - that affective well-being is more related to non-material well-being indicators such as perceived health, personal security, and social connections, in comparison to material ones.

The data also indicated some differences in the regression coefficients and the most important determinants of mental well-being across the age and gender groups. Subjective health is the most important determinant among both genders. It also becomes more crucial as age rises. Satisfaction with family life also has a stronger effect among older age categories, while satisfaction with the standard of living becomes progressively less relevant with inceasing age. Finally, the results showed that during five years between the two survey rounds there was a slight but not significant decline in overall mental well-being. The aforementioned difficult circumstances that shape the mental well-being of the population in Serbia can still be said to have great importance, although they do not aggravate substantially. 
Владимир С. Ментус ${ }^{1}$

Институт друштвених наука

Београд (Србија)

\title{
ДЕТЕРМИНАНТЕ МЕНТАЛНОГ БЛАГОСТАЊА У СРБИЈИ
}

\author{
(Превоg In Extenso)
}

Сажетак: У раду се испитују детерминанте менталног благостања у Србији. Ментално благостање се одређује као стање благостања у којем појединац остварује своје потенцијале, може се носити са стресним животним ситуацијама, може продуктивно и плодоносно да ради и може да да допринос својој заједници. Иако су истраживања детерминанти менталног благостања на национално репрезентативним узорцима из других земаља нашироко заступљена, у Србији су у потпуности занемарена. У раду су коришћени национално репрезентативни узорци из Србије из 2011. и 2016. године који потичу из Европског истраживања о квалитету живота. Подаци су показали да ментално благостање опада са старошћу, посебно међу старијим женама. Друго, самопроцена општег здравственог стања је најзначајнија детерминанта менталног благостања. Оптимизам у погледу своје будућности, осећај напетости и задовољство породичним животом су следећи. Такође су испитани трендови менталног благостања у петогодишњем периоду између два круга истраживања и установљен је његов благ, али не статистички значајан пад.

Кључне речи: ментално благостање, Србија, Европско истраживање о квалитету живота

\section{Увод}

У овом раду испитују се детерминанте менталног благостања међу популацијом у Србији. Светска здравствена организација (WHO, 2004) одређује ментално здравље (које се у литератури најчешће користи као синоним за ментално благостање) као стање благостања у којем појединац остварује своје потенцијале, може се носити са стресним животним ситуацијама, може продуктивно и плодоносно да ради и може да да допринос својој заједници. Још један битан аспект менталног здравља је способност одржавања међусобно задовољавајућих и трајних односа (Tennant et al., 2007).

\footnotetext{
1 vmentus@idn.org.rs

2 Рад је резултат пројекта „Структурне, друштвене и историјске промене српског друштва у контексту европских интеграција и глобализације” (ОИ 179039) који финансира Министарство просвете, науке и технолошког развоја Републике Србије.
} 
Поље позитивног менталног здравља је релативно сложено, и обухвата и афекте и психолошко функционисање кроз две различите перспективе: с једне стране, ту је хедонистичка перспектива, која се фокусира на субјективна искуства задовољства животом и срећу, а с друге стране, ту је еудаимонијска перспектива, заснована на психолошком функционисању и самоостварењу (Tennant et al., 2007). Емпиријска евиденција указује на то да одсуство менталног поремећаја није синоним за ментално здравље, пошто налази указују на независност позитивног и негативног здравља; такође, како позитивно ментално благостање доприноси друштвеном, људском и економском капиталу, његово промовисање је од суштинске важности (Barry, 2013).

Иако су истраживања из ове области на национално репрезентативним узорцима из других земаља широко заступљена, у Србији су у потпуности занемарена ${ }^{3}$. Последње деценије су биле веома тешке за већину популације у Србији; наиме, од деведесетих година прошлог века ту су ратови и миграције стотина хиљада избеглица, економске санкције, огромна хиперинфлација, агресија НАТО-а, и самим тим, драматично осиромашење и економски колапс, уништење здравственог система итд. Данас Србију одликује деиндустријализована економија, изузетно низак ниво економске активности, висока стопа незапослености и емиграције, нарочито младих, раст друштвених неједнакости и сукоба итд. (UNICEF Serbia, 2019; Novaković, 2017; Dušanić, 2017; 2018). Све ово би требало да има значајне негативне ефекте по ментално благостање становништва у Србији.

Још битније, може се очекивати примаран ефекат нематеријалних домена благостања на ментално благостање. Конкретније, најчешће коришћене мере менталног благостања, попут WEMWBS (Tennant et al., 2007), WHO-5 (Topp et al. 2015), PHQ-9 (Kroenke et al., 2001), GHQ (Goldberg et al., 1979), или CES-D (Radloff, 1977), углавном су сачињене од ајтема који мере афективно благостање, а за које се показало да су више повезани с индикаторима нематеријалног благостања (Kahneman and Krueger, 2010; Kahneman and Krueger, 2006). Исто тако, као што је већ показано на национално репрезентативном узорку из Србије (Vladisavljević and Mentus, 2019), афективно благостање је позитивно повезано с многим индикаторима благостања и, у односу на материјалне, више је повезано с нематеријалним индикаторима попут самопроцене здравственог стања, личне сигурности и социјалних веза.

\section{Преглед досадашњих истраживања}

Велики је број истраживања из других земаља у којима се истражују детерминанте менталног благостања. У овом делу укратко се представљају најбитнији налази ових истраживања који указују на очекивану повезаност релевантних детерминанти с менталним благостањем.

- Демоірафске gетерминанйе - Преваленција менталних проблема попут анксиозности и депресије, и поремећаја расположења, већа је међу женама (Klose and Jacobi, 2004), али када је у питању укупно ментално благостање,

\footnotetext{
3 Иако има неколико корисних извештаја заснованих на национално репрезентативним подацима (IZJZS „Batut”, 2008; Boričić et al., 2014; Knežević et al., 2009).
} 
повезаност није толико једноставна. Поједина истраживања указују на веће скорове међу мушкарцима (Stephens et al., 1999), поједина међу женама (Huppert et al., 1989; Ryff and Singer, 1998), док многа истраживања указују и да нема значајних разлика према полу (Diener, 2009; Helliwell, 2003; Donovan and Halpern, 2002).

Повезаност између старости и менталног благостања такође није толико једноставна. Већина истраживања указује на повезаност $U$-облика између различитих показатеља менталног благостања и старости у великом броју земаља (Blanchflower and Oswald, 2008; Clark and Oswald, 1994; Singleton et al., 2001), а такође и на негативан однос (Ferrer-i-Carbonell and Gowdy, 2007), док поједина указују на одсуство повезаности (McKee-Ryan et al., 2005). ${ }^{4}$

Иако смер узрочно-последичне везе није јасан, многа истраживања указују на позитивну повезаност између бивања у браку и менталног благостања (Waite and Gallagher, 2000; Lamb et al., 2003; Simon, 2002; Horwitz et al., 1996; Kim and McKenry, 2002). Поједине студије показују да само склапање брака, а не брак као такав, има позитивне ефекте на ментално благостање (Zimmermann and Easterlin, 2006). С друге стране, доказано је да развод негативно утиче на ментално благостање (Mastekaasa, 1994).

- Социоекономске gетеерминанйе - Образовање је најчешће позитивно повезано с менталним благостањем (Dolan et al., 2008). Нека истраживања су показала, међутим, да је ризик од појаве појединих психичких проблема већи међу онима с вишим нивоом образовања (Fagg et al., 2008). Осим тога, стрес повезан с послом међу занимањима која захтевају високо образовање, као и улога образовања у неиспуњеним очекивањима, могу бити повезани с депресијом (Chevalier and Feinstein, 2006).

Незапосленост је често повезана с лошијим менталним благостањем у крос-секционалним (Fagg et al., 2008; Evans and Repper, 2000), као и у лонгитудиналним истраживањима (Lucas et al., 2004). За виши социоекономски статус је у много наврата указано да је позитивно повезан с физичким и менталним здрављем (Marmot et al., 2012; Quinlan and Bohle, 2009). Показано је да је ризик од депресије и анксиозности повезан с нижим економским статусом, не само у земљама у развоју (Weaver and Hadley 2009; Lund et al., 2010; Whiteford et al., 2013), већ и у богатим земљама (Santana et al., 2015; Lund et al., 2010; Fryers et al. 2005).

- Осйале gетиерминанйе - Откривен је јасан образац позитивне повезаности између физичког и менталног здравља (Nabi et al., 2008; Surtees et al., 2008; Pressman and Cohen, 2006), чак и када се контролишу бројне друге варијабле (Ohrnberger et al., 2017).

Породични живот може бити од кључног значаја за ментално благостање, пошто су досадашња истраживања указала на важност социјалне и емоционалне подршке у том смислу (Almedom, 2005; De Silva et al., 2005; Harrison et al., 1999; Wu et al., 2003; Cairney et al., 2003; Pevalin et al., 2003). Даље, свеобухватне метаанализе су показале да религиозност има позитивног

4 Исто тако, утврђене су интеракције између старости и пола (Huppert and Whittington, 2003). 
ефекта на срећу, регулацију емоција, позитивно благостање и ментални мир (Koenig et al., 2012; Tay et al., 2014; Vishkin et al., 2014). С друге стране, поједина истраживања су указала на врло слабу или безначајну повезаност између религиозности и благостања (Snoep, 2008; Lewis et al., 2005; Lewis, 2002; Lewis et al., 2000).

Живот у руралним подручјима је често повезан са социоекономским тешкоћама, изложеношћу и рањивошћу на еколошке проблеме, лошијом инфраструктуром, тежим приступом здравственим и другим установама, као и географском изолацијом (Inder et al., 2017). С друге стране, дугорочни друштвени проблеми попут више стопе криминала, социјалне изолације, нижег степена социјалне подршке, сиромаштва, високог степена насиља и несрећних случајева, или лоших стамбених услова (који су сви често повезани са животом у урбаном окружењу) чврсто су повезани са депресијом (McKenzie, 2008).

Позитивна и негативна очекивања у погледу будућности су кључна за разумевање рањивости када је реч о менталним поремећајима, нарочито анксиозним и поремећајима расположења (Conversano et al., 2010). Оптимизам је позитивно повезан са самопоштовањем, ређим доживљавањем негативних емоција, позитивним афективитетом и задовољством животом (Ho et al., 2010). Негативно је, такође, повезан с депресивним и анксиозним поремећајима и суицидалним идејама. Оптимизам може значајно утицати на ментално благостање кроз здрав начин живота, као и адаптивним понашањем и когнитивним одговорима повезаним с већом флексибилношћу, капацитетом за решавање проблема и ефикаснијом разрадом негативних информација (Conversano et al., 2010).

\section{Метод}

Подаци коришћени у овом истраживању потичу из European Quality of Life Survey (EQLS). То је истраживање лицем у лице одрасле популације (преко осамнаест година старости) која живи у својим домаћинствима. У оквиру њега се на сваке четири до пет година прикупљају подаци о тренутним животним условима испитаника у многим европским земљама, као и о њиховим ставовима о широком спектру повезаних тема. Оне укључују запосленост, приходе, образовање, стамбене услове, породични живот, здравље, посао и слободно време, задовољство животом, квалитет друштва итд. Значајан број питања из упитника се реплицира из таласа у талас, омогућавајући крос-секционалне анализе трендова (Eurofund, 2018).

До сада су прикупљани национално репрезентативни подаци из Србије у оквиpy EQLS 2011. и 2016. године. Величине узорка за 2011. годину су 1002 (52\% жена, $M_{\text {age }}$ $\left.=47.93, S D_{\text {age }}=17.78\right)$ и 1056 за 2016. годину $\left(51.9 \%\right.$ жена, $\left.M_{\text {age }}=48.79, S D_{\text {age }}=17.38\right)$. Наш спојени узорак се тако састоји од 2058 учесника $\left(51.9 \%\right.$ жена, $M_{\text {age }}=48.37, S D_{\text {age }}$ = 17.58). Засебне узорке користили смо искључиво за вршење анализе трендова.

Изабрана је двадесет и једна варијабла за које је у претходним истраживањима показано да су релевантне детерминанте менталног благостања Табела 1. Поред социо-демографских варијабли попут пола, старости, статуса запослења и брачног 
статуса, нивоа образовања и типа насеља, то су: субјективно здравље, задовољство породичним животом, задовољство животним стандардом, могућност састављања краја с крајем, оптимизам у погледу своје будућности, осећај вредности, осећај слободе одлучивања о томе како да се живи, имање времена за бављење стварима у којима се заиста ужива, осећај посебне напетости (током последње две недеље), осећај усамљености (током последње две недеље), осећај потиштености и депресивности (током последње две недеље), бављење спортом или физичким активностима, присуствовање религијским службама (осим венчања, сахрана или крштења) и социјална искљученост (која се састоји од четири ајтема: осећај напуштености од друштва, осећај компликованог живота, осећај непрепознатости од стране других, и гледање с висине због ситуације на послу или прихода од стране других.

Ментално благостање је мерено помоћу WHO-5 скале (Табела 1. Скорови у оквиру EQLS се рачунају тако што се, прво, рекодују вредности одговора 0 до 5. Затим се сабирају вредности пет одговора, чиме се добијају скорови од 0 до 25 . Да би се добио проценат оцене у рангу од 0 до 100, добијени скор се множи са 4 . Притом, 0 процената представља најгоре могуће, а 100 најбоље могуће ментално здравље (Topp et al. 2015).

На основу прегледа 213 научних чланака, показано је да је WHO-5 међу најчешће коришћеним скалама за мерење субјективног психолошког благостања (Topp et al. 2015). Исто тако, од њеног првог објављивања 1998. године, она је преведена на више од тридесет језика и коришћена у истраживањима широм света. Скала има адекватну валидност како приликом детектовања депресије, тако и као мера исхода у клиничким испитивањима, и успешно се примењује у широком спектру истраживања. У овде коришћеном узорку из Србије, WHO-5 показује висок ниво унутрашње конзистентности $(\alpha=.88)$. Резултати су даље у великој мери представљени према моделу у Capone et al., 2019.

\section{Резултати}

Као што приказује Графикон 1 ментално благостање опада са старошћу, с нешто нижим WHO-5 скоровима међу женама, осим око шездесетих година и у старости, када жене имају значајно ниже скорове менталног благостања $[t(84.426)=3.072, p<$ $.01,95 \%$ CI of difference: $4.373,20.421$, Cohen's $d=0.59]$. Уопштено узев, $t$-тестови указују да жене имају значајно ниже резултате менталног благостања $[t(1,987.494)=$ $3.073, p<.01,95 \%$ CI of difference: $1.075,4.869]$, али са врло слабом величином ефекта (Cohen's $d=0.014)$.

Како је афективно благостање једна од кључних компоненти укупног менталног благостања, испитали смо и полне разлике према три негативна афекта (осећај посебне напетости, осећај усамљености и осећај потиштености и депресије). Т-тестови су указали на већу негативну афективност међу женама, али и овде с врло слабом величином ефекта. (Cohen's $d=0.03, M_{\text {females }}=4.26, S D_{\text {females }}=1.243, M_{\text {males }}=4.41$, $S D_{\text {males }}=1.227$, за осећај посебне напетости; Cohen's $d=0.10, M_{\text {females }}=4.70, S D_{\text {females }}=$ $1.381, M_{\text {males }}=5.03, S D_{\text {males }}=1.230$ за осећај усамљености; Cohen's $d=0.12, M_{\text {females }}=$ $4.59, S D_{\text {females }}=1.36, M_{\text {males }}=4.91, S D_{\text {males }}=1.249$ за осећај потиштености и депресије). 
Спровели смо пет засебних анализа варијансе користећи друге релевантне варијабле као факторе који објашњавају ментално благостање. Могућност састављања краја с крајем, која објашњава 13,1\% варијансе, најзначајнија је детерминанта менталног благостања. Следе статус запослења (који објашњава 8\% варијансе), брачни статус (који објашњава 7,7\% варијансе) и образовање (које објашњава 6,6\% варијансе) Табела 2).

Као што је приказано у Табели 2 они који имају тешкоће у састављању краја с крајем, незапослени дуже од дванаест месеци и они који нису у стању да раде због болести или инвалидитета, као и разведени и удовци и удовице, имају ниже скорове менталног благостања од осталих група. Ментално благостање расте са нивоом образовања. Најзад, тип насеља није значајна детерминанта менталног благостања.

Открили смо, такође, статистички значајну интеракцију између старости и могућности састављања краја с крајем на ментално благостање, $F(30,1969)=2.523, p<.001$, $\eta^{2}=0.037$. Општа анализа варијансе указује да пет детерминанти заједно објашњавају око 33,3\% варијансе менталног благостања. Јединствени доприноси детерминанти опадају када се оне убацују засебно: 5,1\% за могућност састављања краја с крајем, $1,2 \%$ за статус запослења, $0,6 \%$ за брачни статус $0,4 \%$ за образовање и $0 \%$ за тип насеља.

Извршене су вишеструке регресионе анализе помоћу enter и stepwise метода. Користили смо 21 независну варијаблу и укупан узорак од 936 учесника (који нису имали недостајуће вредности на сваку од варијабли). Резултати употребе enter методе приказани су у Табели 3

Одабране независне варијабле збирно објашњавају око $48 \%$ варијансе менталног благостања, $F(21,914)=40.236, p<.001, R^{2}=.480$. Девет варијабли од укупно $21 \mathrm{y}$ овом моделу нису значајне детерминанте менталног благостања на нивоу .05. Stepwise регресиона анализа показала је да је субјективно здравље најјача, објашњавајући око $28,8 \%$ варијансе. На другом месту је оптимизам у погледу своје будућности, доприносећи са додатних 7,2\%. Следе осећај напетости (3,9\%), задовољство породичним животом $(1,8 \%)$, бављење спортом или физичким активностима $(1,8 \%)$, и социјална искљученост $(1,2 \%)$. Осећај слободе у одлучивању о начину живота, ниво образовања, субјективни ниво урбанизације, бивање незапосленим, задовољство животним стандардом и присуство на религијским службама (осим венчања, сахрана или крштења), заједно додају око $2,7 \%$ варијансе. Stepwise регресиона анализа показала је да пол, старост, осећај вредности, имање времена да се раде ствари у којима се заиста ужива, осећај усамљености, осећај потиштености и депресије, неспособност за рад услед болести или инвалидитета, бити разведен или разведена и удовац или удовица нису значајни у овом моделу и због тога су искључени из анализе.

у Табелама 4 п приказани су резултати регресионих анализа према старосним и полним групама користећи enter метод, док Табела 5 такође садржи најзначајније детерминанте за сваку групу засноване на stepwise методу. Овде, четири старосне категорије представљају одраслу особу у настајању (15-25 година), младу одраслост (26-44), средњу одраслост (45-64), и касну одраслост (65 година и преко) (Capone et al., 2019). Резултати су указали на постојање појединих разлика у регресионим коефицијентима и најзначајнијим детерминантама менталног благостања према старосним и полним групама. Субјективно здравље је најважнија детерминанта код оба пола и постаје све важније са повећањем година старости. Задовољство породичним 
животом има јачи ефекат међу старијим старосним категоријама, док задовољство животним стандардом постепено опада са старошћу.

Анализирали смо и трендове менталног благостања између два таласа $E Q L S$, поделивши наш спојени узорак према таласима. $T$-тест је указао на благи, мада не значајан пад менталног благостања током ових пет година ( $p>0.05)$. Пад је донекле видљив у ставци „Мој свакодневни живот је испуњен стварима које ме интересују” (Cohen's $d=-0.19, M_{2016}=3.46, M_{2011}=3.22, S D_{2016}=1.21, S D_{2011}=1.30$ ).

\section{Сажетак резултата и закључци}

Користећи национално репрезентативне податке из European Quality of Life Survey из 2011. и 2016. године, испитали смо детерминанте менталног благостања популације Србије. Резултати су указали да ментално благостање опада с годинама старости, и на ниже скорове међу женама у најстаријим старосним категоријама. Непостојање повезаности између старости и менталног благостања у облику слова $U$, што је било утврђено у многим претходним истраживањима, сугерише да се старији људи релативно теже носе са поменутим тешким околностима, нарочито у поређењу са старијим људима из других (углавном богатијих) земаља. То се посебно односи на жене у Србији и може се објаснити налазима према којима је значај здравља - као суштинске детерминанте менталног благостања уопште и индикатора према којем жене углавном стоје лошије- посебно наглашен у старијем животном добу. Субјективно здравље се поново показује као најзначајнија детерминанта менталног благостања, као и у многим другим земљама. Друга по значају детерминанта је оптимизам у погледу своје будућности, праћен осећајем напетости и задовољством породичним животом. Суштински ефекти оптимизма, негативних афеката уопште и задовољство породичним животом такође су били пронађени у многим претходним истраживањима.

Даље, како је такође било очекивано, резултати су генерално указали на значај нематеријалних домена живота за ментално благостање у Србији. Објашњење за то може се наћи у чињеници да се WHO-5 скала, као и друге најчешће коришћене мере менталног благостања, састоје од ајтема који мере афективно благостање, а за које се показало да су више везани за индикаторе нематеријалног благостања. Овај налаз је у складу с претходним налазом на национално репрезентативном узорку из Србије - да је афективно благостање више повезано с индикаторима материјалног благостања, као што су субјективно здравље, лична сигурност и социјалне везе, у поређењу с материјалним.

Подаци су указали на поједине разлике у регресионим коефицијентима и најзначајнијим детерминантама менталног благостања у односу на старосне и полне групе. Субјективно здравље је најзначајнија детерминанта код оба пола. Оно постаје све значајније с растом старости. Задовољство породичним животом такође има јачи ефекат код старијих испитаника, док задовољство животним стандардом постаје све мање значајно с годинама. Коначно, резултати су показали да је током пет година између два круга испитивања дошло до благог, али не значајног пада укупног менталног благостања. За горе поменуте тешке околности које обликују ментално благостање становништва у Србији и даље се може рећи да имају велики значај, иако се нарочито не погоршавају. 


\section{REFERENCES / ЛИTЕРATУPA}

Barry, M. (2013). Promoting positive mental health and well-being: Practice and policy. In: C. L. M. Keyes (Ed.), Mental well-being: International contributions to the study of positive mental health (pp. 355-384). New York: Springer Science and Business Media.

Boričić, K. et al. (2014). Results of the research of the population health in Serbia, 2013. Beograd: Institut za javno zdravlje Srbije "Dr Milan Jovanović Batut”. [In Serbian]

Cairney, J., Boyle, M., Offord, D. R., and Racine, Y. (2003). Stress, social support and depression in single and married mothers. Social Psychiatry and Psychiatric Epidemiology, 38(8), 442-449.

Campion, J., Bhui, K., and Bhugra, D. (2012). European Psychiatric Association (EPA) guidance on prevention of mental disorders. European Psychiatry, 27(2), 68-80.

Capone, V., Joshanloo, M., and Scheifinger, H. (2019). Predictors of life satisfaction in a large representative sample from Italy. Current Psychology. First online. DOI: 10.1007/s12144-019-00305-x

Chevalier, A., and Feinstein, L. (2006). Sheepskin or Prozac: The causal effect of education on mental health. Report published by the Centre for the Economics of Education, London School of Economics, London.

Clark, A. E. (2003). Unemployment as a Social Norm: Psychological Evidence from Panel Data. Journal of Labor Economics, 21(2), 323-351.

Cohen, S., and Pressman, S. D. (2006). Positive Affect and Health. Current Directions in Psychological Science, 15(3), 122-125.

De Silva, M. J., McKenzie, K., Harpham, T., and Huttly, S. R. A. (2005). Social capital and mental illness: A systematic review. Journal of Epidemiology and Community Health, 59(8), 619-627.

Diener, E. (2009). Subjective well-being. In E. Diener (Ed.), The science of well-being: The collected works of Ed Diener (pp. 11-58). New York: Springer.

Donovan, N., and Halpern, D. (2002). Life satisfaction: The state of knowledge and implications for government. Prime Minister's Strategy Unit, discussion paper.

Dušanić, J. (2017). Bećar-style Economy. Beograd: Beogradska poslovna škola - Visoka škola strukovnih studija. [In Serbian]

Dušanić, J. (2018). Why are we condemned to economic regression? Available at: http:// www.nspm.rs/ekonomska-politika/zbog-cega-smo-osudjeni-na-ekonomskonazadovanje.html?alphabet=1 [In Serbian]

Eurofound (2018). European Quality of Life Survey 2016: Quality Assessment. On-line working paper.https://www.eurofound.europa.eu/sites/default/files/wpef18059.pdf

Evans, J., and Repper, J. (2000). Employment, social inclusion and mental health. Journal of Psychiatric and Mental Health Nursing, 7(1), 15-24.

Fagg, J., Curtis, S., Stansfeld, S. A., Cattell, V., Tupuola, A.-M., and Arephin, M. (2008). Area social fragmentation, social support for individuals and psychosocial health in young adults: Evidence from a national survey in England. Social Science and Medicine, 66(2), 242-254. 
Ferrer-i-Carbonell, A. and Gowdy, J. M. (2007), Environmental degradation and happiness, Ecological Economics, 60(3), 509-516.

Fryers, T., Melzer, D., Jenkins, R., et al (2005), The distribution of the common mental disorders: social inequalities in Europe. Journal of Public Mental Health, 1, 1-12.

Goldberg, D. P., \& Hillier, V. F. (1979). A scaled version of the General Health Questionnaire. Psychological Medicine, 9(1),139-145.

Harrison, J., Barrow, S., Gask, L., and Creed, F. (1999). Social determinants of GHQ score by postal survey. Journal of Public Health, 21(3), 283-288.

Helliwell, J. F. (2003). How's life? Combining individual and national variables to explain subjective well-being. Economic Modelling, 20, 331-360.

Hidaka, B. H. (2012). Depression as a disease of modernity: Explanations for increasing prevalence. Journal of Affective Disorders, 140(3), 205-214.

Horwitz, A. V., White, H. R., and Howell-White, S. (1996). Becoming married and mental health: A longitudinal study of a cohort of young adults. Journal of Marriage and the Family, 58, 895-907.

Huppert, F. A. (2009). A new approach to reducing disorder and improving well-being. Perspectives on Psychological Science, 4(1), 108-111.

Huppert, F. A., and Whittington, J. E. (2003). Evidence for the independence of positive and negative well-being: Implications for quality of life assessment. British Journal of Health Psychology, 8, 107-122.

Inder, K., Holliday, E., Handley, T., Fragar, L., Lower, T., Booth, A., ... Kelly, B. (2017). Depression and Risk of Unintentional Injury in Rural Communities - A Longitudinal Analysis of the Australian Rural Mental Health Study. International Journal of Environmental Research and Public Health, 14(9), 1080.

IZJZS „Batut” (2008). Health of the population in Serbia: analytical study 1997-2007. Beograd: Institut za javno zdravlje Srbije "Dr Milan Jovanović Batut”. [In Serbian]

Kahneman, D., and Deaton, A. (2010). High income improves evaluation of life but not emotional well-being. Proceedings of the National Academy of Sciences, 107(38), 16489-16493.

Kahneman, D., and Krueger, Alan (2006). Developments in the measurement of subjective well-being. Journal of Economic Perspectives, 20, 3-24.

Kim, H. and McKenry, P. C. (2002). The Relationship between Marriage and Psychological Well-being. Journal of Family Issues, 23(8), 885-911.

Klose, M., and Jacobi, F. (2004). Can gender differences in the prevalence of mental disorders be explained by sociodemographic factors? Archives of Women's Mental Health, 7(2), 133-148.

Knežević, T., Simić, D., Ivanović, I. (2009). Health of the Young in the Republic of Serbia Final Report. Beograd: Institut za javno zdravlje Srbije „Dr Milan Jovanović Batut“.

Koenig, H. G., King, D. E., and Carson, V. B. (2012). Handbook of religion and health (2nd ed.). New York: Oxford University Press.

Kroenke, K., Spitzer, R. L., \& Williams, J. B. W. (2001). The PHQ-9. Journal of General Internal Medicine, 16(9), 606-613.

Lamb K. A., Lee G. R., and DeMaris A. (2003). Union formation and depression: Selection and relationship effects. Journal of Marriage and Family, 65, 953-962. 
Lewis, C. A. (2002). Church attendance and happiness among Northern Irish undergraduate students: No association. Pastoral Psychology, 50(3), 191-195.

Lewis, C. A., Maltby, J., and Burkinshaw, S. (2000). Religion and happiness: Still no association. Journal of Beliefs and Values, 21(2), 233-236.

Lewis, C. A., Maltby, J., and Day, L. (2005). Religious orientation, religious coping and happiness among U.K. adults. Personality and Individual Differences, 38(5), 11931202.

Lucas, R. E., Clark, A. E., Georgellis, Y., and Diener, E. (2004). Unemployment alters the set point for life satisfaction. Psychological Science, 15, 8-13.

Lund, C., Breen, A., Flisher, A. J., Kakuma, R., Corrigall, J., Joska, J. A., Swartz, L., and Patel, V. (2010). Poverty and common mental disorders in low and middle income countries: A systematic review. Social Science and Medicine, 71, 517-528.

Marmot, M., Allen, J., Bell, R., Bloomer, E., and Goldblatt, P. (2012). WHO European review of social determinants of health and the health divide. The Lancet, 380(9846), 1011-1029.

Mastekaasa, A. (1994). Psychological well-being and marital dissolution: Selection effects. Journal of Family Issues, 15, 208-228.

McKee-Ryan, F., Song, Z., Wanberg, C. R., and Kinicki, A. J. (2005). Psychological and Physical Well-Being During Unemployment: A Meta-Analytic Study. Journal of Applied Psychology, 90(1), 53-76.

McKenzie, K. (2008). Urbanization, Social Capital and Mental Health. Global Social Policy: An Interdisciplinary Journal of Public Policy and Social Development, 8(3), 359-377.

Nabi, H., Kivimaki, M., Vogli, R. D., Marmot, M. G., and Singh-Manoux, A. (2008). Positive and negative affect and risk of coronary heart disease: Whitehall II prospective cohort study. British Medical Journal, 337: a118.

Novaković, N. (2017). Workers' Strikes and Transition in Serbia from 1990 to 2015. Beograd: Rosa-Luxemburg-Stiftung Southeast Europe,... Institut društvenih nauka. [In Serbian]

Ohrnberger, J., Fichera, E., and Sutton, M. (2017). The dynamics of physical and mental health in the older population. The Journal of the Economics of Ageing, 9, 52-62.

Pevalin DJ, Goldberg DP (2003). Social precursors to onset and recovery from episodes of common mental illness. Psychological Medicine, 33(2), 299-306.

Quinlan, M., and Bohle, P. (2009). Overstretched and Unreciprocated Commitment: Reviewing Research on the Occupational Health and Safety Effects of Downsizing and Job Insecurity. International Journal of Health Services, 39(1), 1-44.

Radloff, L. S. (1977). The CES-D Scale: A self-report depression scale for research in the general population. Applied Psychological Measurement, 1(3), 385-401.

Ryff, C. D., and Singer, B. H. (1998). The contours of positive human health. Psychological Inquiry, 9(1), 1-28.

Santana, P., Costa, C., Cardoso, G., Loureiro, A., and Ferrão, J. (2015). Suicide in Portugal: Spatial determinants in a context of economic crisis. Health and Place, 35, 85-94.

Shields, M.A. and Wheatley Price, S. (2005). Exploring the economic and social determinants of psychological well-being and perceived social support in England. Journal of the Royal Statistical Society, 168, Series A (Issue 3), 513-537. 
Simon R. W. (2002). Revisiting the relationships among gender, marital status, and mental health. American Journal of Sociology, 107, 1065-1096.

Snoep, L. (2008). Religiousness and happiness in three nations: A research note. Journal of Happiness Studies, 9(2), 207-211.

Stephens, T., Dulberg, C., and Joubert, N. (1999). Mental health of the Canadian population: A comprehensive analysis. Chronic Diseases in Canada, 20, 118-126.

Surtees, P. G., Wainwright, N. W. J., Luben, R. N., Wareham, N. J., Bingham, S. A., and Khaw, K.-T. (2008). Psychological distress, major depressive disorder, and risk of stroke. Neurology, 70(10), 788-794.

Tay, L., Li, M., Myers, D., and Diener, E. (2014). Religiosity and subjective well-being: An international perspective. In: C. Kim-Prieto (Ed.), Religion and spirituality across cultures (pp. 163-175). Dordrecht: Springer.

Tennant, R., Hiller, L., Fishwick, R., Platt, S., Joseph, S., Weich, S., ... Stewart-Brown, S. (2007). The Warwick-Edinburgh Mental Well-being Scale (WEMWBS): development and UK validation. Health and Quality of Life Outcomes, 5(1), 63.

Topp, C. W., Østergaard, S. D., Søndergaard, S., and Bech, P. (2015). The WHO-5 WellBeing Index: A Systematic Review of the Literature. Psychotherapy and Psychosomatics, 84(3), 167-176.

Twenge, J. M., Gentile, B., DeWall, C. N., Ma, D., Lacefield, K., and Schurtz, D. R. (2010). Birth cohort increases in psychopathology among young Americans, 19382007: A cross-temporal meta-analysis of the MMPI. Clinical Psychology Review, 30(2), 145-154.

UNICEF Serbia (2019). Adverse Childhood Experiences (ACE) Study Research on Adverse Childhood Experiences in Serbia. Belgrade: UNICEF in Serbia.

Vishkin, A., Bigman, Y. E., and Tamir, M. (2014). Religion, emotion regulation, and wellbeing. In: C. Kim-Prieto (Ed.), Religion and Spirituality across cultures (pp. 247-269). Dordrecht: Springer.

Vladisavljević, M., and Mentus, V. (2018). The Structure of Subjective Well-Being and Its Relation to Objective Well-Being Indicators: Evidence from EU-SILC for Serbia. Psychological Reports, 122 (1), 36-60.

Waite L., and Gallagher M. (2000). The case for marriage: Why married people are happier, healthier and better off financially. New York: Doubleday.

Weaver, L. J., and Hadley, C. (2009). Moving Beyond Hunger and Nutrition: A Systematic Review of the Evidence Linking Food Insecurity and Mental Health in Developing Countries. Ecology of Food and Nutrition, 48(4), 263-284.

WHO (2004): Promoting Mental Health; Concepts emerging evidence and practice. Summary report. Geneva: World Health Organisation.

Wu, Z., Penning, M. J., Pollard, M. S., and Hart, R. (2003). "In sickness and in health": Does cohabitation count? Journal of Family Issues, 24(6), 811-838.

Zimmermann A. C., and Easterlin R. A. (2006). Happily ever after? Cohabitation, marriage, divorce, and happiness in Germany. Population and Development Review, $32,511-528$. 


\section{ПРИЛОГ / АРРЕNDIX}

Table 1: Variables used in the study/

Табела 1: Варијабле коришћене у истраживању

\begin{tabular}{|c|c|c|}
\hline Variable/Варијабла & Item/Ајтем & $\begin{array}{c}\text { Response format/ } \\
\text { Одговори }\end{array}$ \\
\hline \multirow{10}{*}{$\begin{array}{c}\text { Mental well-being/ } \\
\text { Ментално благостање }\end{array}$} & \multirow{2}{*}{$\begin{array}{l}\text { I have felt cheerful and in good spirits } \\
\text { (over the last two weeks)./ } \\
\text { Осећао сам се весело и расположено } \\
\text { (током последње две недеље). }\end{array}$} & 1 All of the time \\
\hline & & $\begin{array}{l}6 \text { At no time } \\
1 \text { Све време } \\
6 \text { Ни у једном моменту }\end{array}$ \\
\hline & \multirow{2}{*}{$\begin{array}{l}\text { I have felt calm and relaxed (over the } \\
\text { last two weeks). / } \\
\text { Oceћаo сам се смирено и опуштено } \\
\text { (током последње две недеље). }\end{array}$} & 1 All of the time \\
\hline & & $\begin{array}{l}6 \text { At no time } \\
1 \text { Све време } \\
6 \text { Ни у једном моменту }\end{array}$ \\
\hline & \multirow{2}{*}{$\begin{array}{l}\text { I have felt active and vigorous (over the } \\
\text { last two weeks)./ } \\
\text { Осећао сам се активно и енергично } \\
\text { (током последње две недеље). }\end{array}$} & 1 All of the time \\
\hline & & $\begin{array}{l}6 \text { At no time } \\
1 \text { Све време } \\
6 \text { Ни у једном моменту }\end{array}$ \\
\hline & \multirow{2}{*}{$\begin{array}{l}\text { I woke up feeling fresh and rested (over } \\
\text { the last two weeks)./ } \\
\text { Пробудио сам се осећајући се свеже } \\
\text { и одморно (током последње две } \\
\text { недеље). }\end{array}$} & 1 All of the time \\
\hline & & $\begin{array}{l}6 \text { At no time } \\
1 \text { Све време } \\
6 \text { Ни у једном моменту }\end{array}$ \\
\hline & \multirow{2}{*}{$\begin{array}{l}\text { My daily life has been filled with things } \\
\text { that interest me (over the last two } \\
\text { weeks)./ } \\
\text { Мој свакодневни живот је испуњен } \\
\text { стварима које ме интересују (током } \\
\text { последње две недеље). }\end{array}$} & 1 All of the time \\
\hline & & $\begin{array}{l}6 \text { At no time } \\
1 \text { Све време } \\
6 \text { Ни у једном моменту }\end{array}$ \\
\hline \multirow[b]{2}{*}{$\begin{array}{c}\text { Subjective health/ } \\
\text { Субјективно здравље }\end{array}$} & \multirow[b]{2}{*}{$\begin{array}{c}\text { In general, how is your health?/ } \\
\text { Уопштено говорећи, какво је Ваше } \\
\text { здравље? }\end{array}$} & 1 Very good \\
\hline & & $\begin{array}{l}5 \text { Very bad } \\
1 \text { Врло добро } \\
5 \text { Врло лоше } \\
\end{array}$ \\
\hline \multirow{2}{*}{$\begin{array}{c}\text { Satisfaction with } \\
\text { family life/ } \\
\text { Задовољство } \\
\text { породичним животом/ }\end{array}$} & \multirow[b]{2}{*}{$\begin{array}{c}\text { How satisfied you are with family life?/ } \\
\text { Колико сте задовољни породичним } \\
\text { животом? }\end{array}$} & 1 Very dissatisfied \\
\hline & & $\begin{array}{l}10 \text { Very satisfied } \\
1 \text { Врло незадовољан/на } \\
10 \text { Врло задовољан/на }\end{array}$ \\
\hline \multirow{2}{*}{$\begin{array}{l}\text { Satisfaction with the } \\
\text { standard of living/ } \\
\text { Задовољство животним } \\
\text { стандардом }\end{array}$} & \multirow{2}{*}{$\begin{array}{l}\text { How satisfied you are with the standard } \\
\text { of living?/ } \\
\text { Колико сте задовољни животним } \\
\text { стандардом? }\end{array}$} & 1 Very dissatisfied \\
\hline & & $\begin{array}{l}10 \text { Very satisfied } \\
1 \text { Врло незадовољан/на } \\
10 \text { Врло задовољан/на }\end{array}$ \\
\hline
\end{tabular}




\begin{tabular}{|c|c|c|}
\hline Variable/Варијабла & Item/Ајтем & $\begin{array}{l}\text { Response format/ } \\
\text { Одговори }\end{array}$ \\
\hline \multirow[t]{2}{*}{ Optimism/Оптимизам } & \multirow{2}{*}{$\begin{array}{c}\text { I am optimistic about my future./ } \\
\text { Ја сам оптимиста што се тиче моје } \\
\text { будућности. }\end{array}$} & \begin{tabular}{|l|}
1 Strongly agree \\
5 Strongly disagree \\
1 Потпуно се слажем
\end{tabular} \\
\hline & & 5 Уопште се не слажем \\
\hline $\begin{array}{l}\text { Ability to make ends } \\
\text { meet/ } \\
\text { Могућност састављања } \\
\text { краја са крајем }\end{array}$ & $\begin{array}{c}\text { Is your household able to make ends } \\
\text { meet?/ } \\
\text { Да ли је Ваше домаћинство у стању да } \\
\text { састави крај с крајем? }\end{array}$ & $\begin{array}{l}1 \text { Very easily } \\
6 \text { With great difficulty } \\
1 \text { Врло лако } \\
6 \text { Уз велике тешкоће }\end{array}$ \\
\hline \multirow[t]{2}{*}{ Worthwhile/Вредност } & \multirow{2}{*}{$\begin{array}{c}\text { I generally feel that what I do in life is } \\
\text { worthwhile./ } \\
\text { Ја у принципу сматрам да оно што } \\
\text { радим у животу вреди. }\end{array}$} & $\begin{array}{l}1 \text { Strongly agree } \\
5 \text { Strongly disagree } \\
1 \text { Потпуно се слажем } \\
\end{array}$ \\
\hline & & 5 Уопште се не слажем \\
\hline \multirow[t]{2}{*}{ Free/Слобода } & \multirow{2}{*}{$\begin{array}{l}\text { I feel I am free to decide how to live my } \\
\text { life./ } \\
\text { Сматрам да имам слободу да одлучим } \\
\text { како да живим свој живот. }\end{array}$} & \begin{tabular}{|l}
1 Strongly agree \\
5 Strongly disagree \\
1 Потпуно се слажем \\
\end{tabular} \\
\hline & & 5 Уопште се не слажем \\
\hline \multirow[t]{2}{*}{ Time/Време } & \multirow{2}{*}{$\begin{array}{l}\text { In my daily life, I seldom have time to do } \\
\text { the things I really enjoy./ } \\
\text { У свом свакодневном животу, ретко } \\
\text { имам времена да радим ствари у } \\
\text { којима заиста уживам. }\end{array}$} & \begin{tabular}{|l} 
Strongly agree \\
5 Strongly disagree \\
1 Потпуно се слажем \\
\end{tabular} \\
\hline & & 5 Уопште се не слажем \\
\hline \multirow[b]{2}{*}{ Tense/Напетост } & \multirow{2}{*}{$\begin{array}{l}\text { I have felt particularly tense (over the } \\
\text { last two weeks)./ } \\
\text { Oceћао сам се посебно напето (током } \\
\text { последње две недеље). }\end{array}$} & 1 All of the time \\
\hline & & $\begin{array}{l}6 \text { At no time } \\
1 \text { Све време } \\
6 \text { Ни у једном моменту }\end{array}$ \\
\hline \multirow[b]{2}{*}{ Lonely/Усамљеност } & \multirow{2}{*}{$\begin{array}{l}\text { I have felt lonely (over the last two } \\
\text { weeks)./ } \\
\text { Oceћаo сам се усамљено (током } \\
\text { последње две недеље). }\end{array}$} & 1 All of the time \\
\hline & & \begin{tabular}{|l}
6 At no time \\
1 Све време \\
6 Ни у једном моменту
\end{tabular} \\
\hline \multirow{2}{*}{$\begin{array}{c}\text { Downhearted and de- } \\
\text { pressed/ } \\
\text { Депресивност }\end{array}$} & \multirow{2}{*}{$\begin{array}{l}\text { I have felt downhearted and depressed } \\
\text { (over the last two weeks)./ } \\
\text { Осећао сам се потиштено и утучено } \\
\text { (током последње две недеље). }\end{array}$} & 1 All of the time \\
\hline & & \begin{tabular}{|l}
6 At no time \\
1 Све време \\
6 Ни у једном моменту
\end{tabular} \\
\hline \multirow[b]{2}{*}{$\begin{array}{l}\text { Exercise/ } \\
\text { Вежбање }\end{array}$} & \multirow{2}{*}{$\begin{array}{l}\text { How frequently do you take part in } \\
\text { sports or physical exercise?/ } \\
\text { Колико често се бавите спортом или } \\
\text { физичкком активношћу? }\end{array}$} & $\begin{array}{l}1 \text { Every day or almost } \\
\text { every day }\end{array}$ \\
\hline & & $\begin{array}{l}5 \text { Never } \\
1 \text { Свакодневно или } \\
\text { скоро свакодневно } \\
5 \text { Никада } \\
\end{array}$ \\
\hline \multirow[b]{2}{*}{$\begin{array}{c}\text { Religious/ } \\
\text { Религиозност }\end{array}$} & \multirow[b]{2}{*}{$\begin{array}{l}\text { How frequently do you attend religious } \\
\text { services, apart from weddings, funerals } \\
\text { or christenings }\end{array}$} & $\begin{array}{l}1 \text { Every day or almost } \\
\text { every day }\end{array}$ \\
\hline & & \begin{tabular}{|l|}
5 Never \\
1 Свакодневно или \\
скоро свакодневно \\
5 Никада
\end{tabular} \\
\hline
\end{tabular}




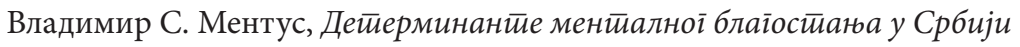

\begin{tabular}{|c|c|c|}
\hline Variable/Варијабла & Item/Ајтем & $\begin{array}{l}\text { Response format/ } \\
\text { Одговори }\end{array}$ \\
\hline \multirow{8}{*}{$\begin{array}{l}\text { Social Exclusion/ } \\
\text { Друштвена } \\
\text { искљученост }\end{array}$} & \multirow[t]{2}{*}{$\begin{array}{c}\text { I feel left out of society./ } \\
\text { Oceћам ce напуштеним од друштва. }\end{array}$} & $\begin{array}{l}1 \text { Strongly agree } \\
5 \text { Strongly disagree } \\
1 \text { Потпуно се слажем }\end{array}$ \\
\hline & & 5 Уопште се не слажем \\
\hline & \multirow{2}{*}{$\begin{array}{l}\text { Life has become so complicated today } \\
\text { that I almost can't find my way./ } \\
\text { Живот је данас постао толико } \\
\text { компликован да скоро да нисам у } \\
\text { стању да нађем свој пут. }\end{array}$} & $\begin{array}{l}1 \text { Strongly agree } \\
5 \text { Strongly disagree } \\
1 \text { Потпуно се слажем } \\
\end{array}$ \\
\hline & & 5 Уопште се не слажем \\
\hline & \multirow{2}{*}{$\begin{array}{l}\text { I feel that the value of what I do is not } \\
\text { recognised by others./ } \\
\text { Не осећам да други људи цене оно } \\
\text { што ја радим. }\end{array}$} & \begin{tabular}{|l}
1 Strongly agree \\
5 Strongly disagree \\
1 Потпуно се слажем \\
\end{tabular} \\
\hline & & 5 Уопште се не слажем \\
\hline & \multirow{2}{*}{$\begin{array}{c}\text { Some people look down on me because } \\
\text { of my job situation or income./ } \\
\text { Неки људи ме гледају са } \\
\text { потцењивањем због моје ситуације са } \\
\text { послом или мојих прихода. }\end{array}$} & \begin{tabular}{|l|}
1 Strongly agree \\
5 Strongly disagree \\
1 Потпуно се слажем \\
\end{tabular} \\
\hline & & 5 Уопште се не слажем \\
\hline
\end{tabular}

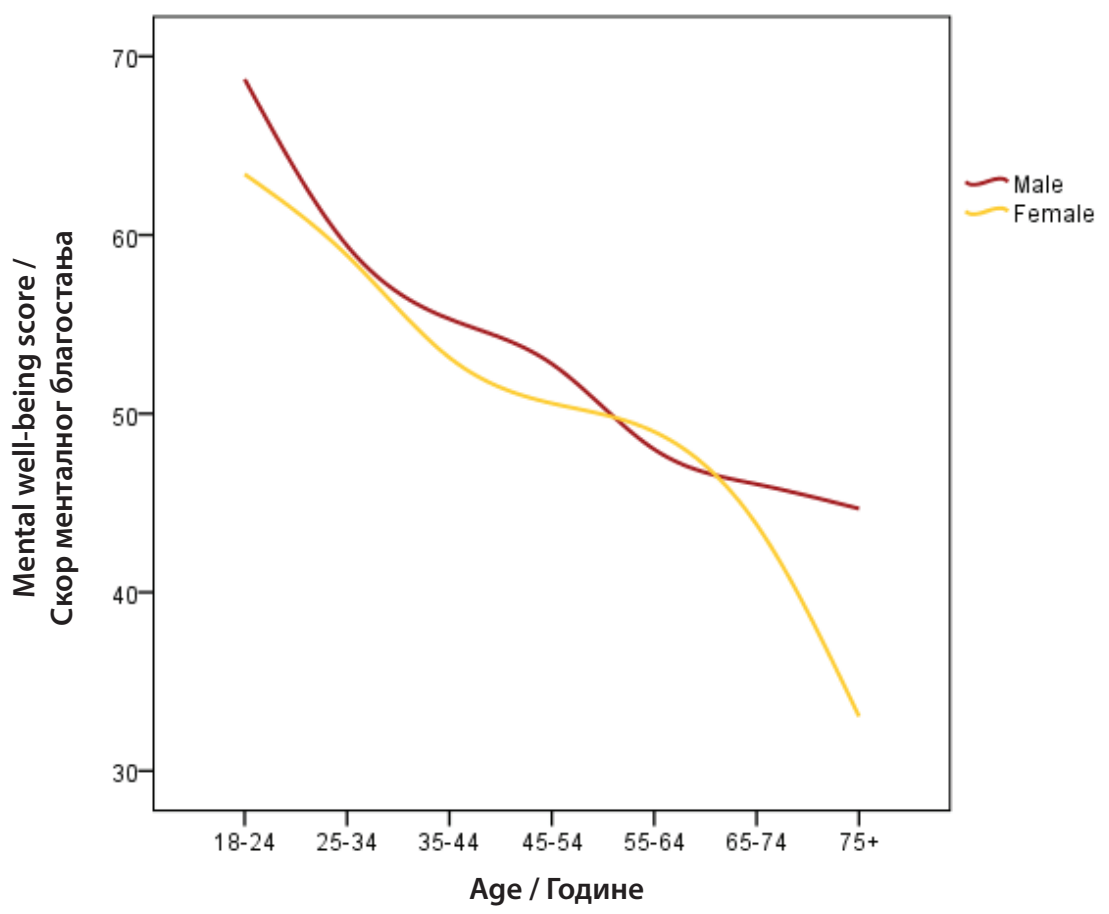

Figure 1: Mental well-being by age and gender/ Графикон 1: Ментално благостање према старости и полу 
Table 2: ANOVA results predicting mental well-being/

Табела 2: Резултати анализе варијансе у предвиђању менталног благостања

\begin{tabular}{|c|c|c|c|c|}
\hline & \multirow{3}{*}{$\begin{array}{c}M \\
55.34\end{array}$} & \multirow{3}{*}{$\begin{array}{c}S D \\
19.80\end{array}$} & \multirow{3}{*}{$\begin{array}{c}N \\
727\end{array}$} \\
\hline & & & & \\
\hline $\begin{array}{c}\text { Employment/Статус } \\
\text { запослења }\end{array}$ & Employed/ Запослен & & & \\
\hline$d f=7,1986$ & $\begin{array}{l}\text { Unemployed }<12 \text { months/ } \\
\text { Незапослен }<12 \text { месеци }\end{array}$ & 56.84 & 20.34 & 94 \\
\hline$F=23.99$ & $\begin{array}{l}\text { Unemployed } 12 \text { months</ } \\
\text { Незапослен } 12 \text { месеци< }\end{array}$ & 51.08 & 22.41 & 294 \\
\hline$p<.001$ & $\begin{array}{c}\text { Unable to work due to illness or } \\
\text { disability/Радно неспособан због } \\
\text { болести или инвалидитета }\end{array}$ & 41.89 & 29.91 & 8 \\
\hline \multirow[t]{5}{*}{$\eta^{2}=.080$} & Retired/Пензионер & 46.56 & 21.64 & 580 \\
\hline & Homemaker/Домаћица & 48.13 & 23.79 & 117 \\
\hline & Student/ Студент & 67.78 & 16.28 & 170 \\
\hline & Other/Друго & 32.05 & 24.73 & 3 \\
\hline & Total/Укупно & 52.77 & 21.64 & 1994 \\
\hline $\begin{array}{l}\text { Education/ } \\
\text { Образовање }\end{array}$ & $\begin{array}{c}\text { Lower secondary or below/ Ниже или } \\
\text { основно образовање }\end{array}$ & 41.27 & 22.54 & 385 \\
\hline$d f=2,1979$ & $\begin{array}{l}\text { Upper secondary or post-secondary/ } \\
\text { Завршена средња школа и више }\end{array}$ & 55.21 & 20.64 & 1272 \\
\hline$F=75.10$ & Tertiary/ Трећи степен & 57.27 & 19.36 & 326 \\
\hline$p<.001$ & Total/ Укупно & 52.84 & 21.59 & 1983 \\
\hline \multicolumn{5}{|l|}{$\eta^{2}=.066$} \\
\hline $\begin{array}{l}\text { Ability to make ends meet/ } \\
\text { Могућност састављања } \\
\text { краја са крајем }\end{array}$ & Very easily/ Веома лако & 65.11 & 21.29 & 40 \\
\hline$d f=5,1947$ & Easily/ Лако & 60.67 & 24.73 & 132 \\
\hline$F=58.05$ & Fairly easily/ Умерено лако & 60.42 & 16.87 & 374 \\
\hline$p<.001$ & With some difficulty & 54.81 & 19.67 & 797 \\
\hline \multirow[t]{3}{*}{$\eta^{2}=.131$} & With difficulty/Тешко & 45.40 & 21.33 & 398 \\
\hline & With great difficulty/Крајње тешко & 36.23 & 22.56 & 213 \\
\hline & Total/Укупно & 52.55 & 21.70 & 1953 \\
\hline $\begin{array}{l}\text { Legal marital status/Брачни } \\
\text { статус }\end{array}$ & Never married/Без претходног брака & 62.56 & 18.27 & 210 \\
\hline$d f=4,1006$ & Married/У браку & 49.99 & 20.90 & 658 \\
\hline$F=20.94$ & Separated/Раздвојен/а & 47.98 & 17.32 & 19 \\
\hline$p<.001$ & Widowed/Удовац/удовица & 43.54 & 20.35 & 106 \\
\hline
\end{tabular}




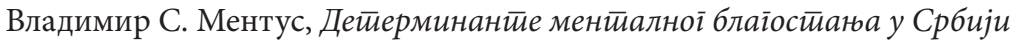

\begin{tabular}{|c|c|c|c|c|}
\hline$\eta^{2}=.077$ & Divorced/Разведен/а & 46.72 & 21.73 & 18 \\
\hline Location/Тип насеља & Rural/Сеоско & 52.92 & 22.28 & 974 \\
\hline$d f=1,1983$ & Urban/Градско & 52.72 & 20.96 & 1011 \\
\hline$F=0.043$ & Total/Укупно & 52.82 & 21.61 & 1986 \\
\hline$p>0.05$ & & & & \\
\hline$\eta^{2}=.000$ & & & & \\
\hline
\end{tabular}

Table 3: Results of the Regression Analysis/

Табела 3: Резултати регресионе анализе

\begin{tabular}{|c|c|c|c|c|c|c|c|}
\hline & \multirow[t]{2}{*}{$B$} & \multicolumn{2}{|c|}{\begin{tabular}{|c|}
$95.0 \%$ Confidence \\
Interval for B / \\
$95,0 \%$ интервал \\
поверења за B \\
\end{tabular}} & \multirow[t]{2}{*}{$t$} & \multirow[t]{2}{*}{$p$} & \multirow[t]{2}{*}{ Beta } & \multirow{2}{*}{$\begin{array}{l}\text { Semi-partial } \\
\text { correlation / } \\
\text { Делимична } \\
\text { корелација }\end{array}$} \\
\hline & & $\begin{array}{l}\text { Low/ } \\
\text { Низак }\end{array}$ & $\begin{array}{c}\text { Up/У } \\
\text { порасту }\end{array}$ & & & & \\
\hline (Constant)/ (Константа) & 54.252 & 41.570 & 66.935 & 8.395 & .000 & - & - \\
\hline Female/Женско & 1.062 & -1.076 & 3.200 & .975 & .330 & .025 & .023 \\
\hline Age/Старост & .783 & -.087 & 1.652 & 1.766 & .078 & .063 & .042 \\
\hline $\begin{array}{c}\text { Subjective health/ } \\
\text { Субјективно здравље }\end{array}$ & -5.403 & -6.782 & -4.023 & -7.687 & .000 & -.278 & -.183 \\
\hline $\begin{array}{l}\text { Satisfaction with the stan- } \\
\text { dard of living/ } \\
\text { Задовољство животним } \\
\text { стандардом/ }\end{array}$ & .562 & .096 & 1.028 & 2.369 & .018 & .070 & .056 \\
\hline $\begin{array}{c}\text { Satisfaction with family life } \\
\text { Задовољство/ породичним } \\
\text { животом }\end{array}$ & 1.181 & .607 & 1.755 & 4.040 & .000 & .117 & .096 \\
\hline $\begin{array}{c}\text { Optimism about own future/ } \\
\text { Оптимизам } \\
\end{array}$ & -2.284 & -3.474 & -1.095 & -3.768 & .000 & -.121 & -.090 \\
\hline Worthwhile/Вредност & -.205 & -1.633 & 1.223 & -.281 & .779 & -.009 & -.007 \\
\hline Free/Слобода & -1.837 & -3.031 & -.643 & -3.019 & .003 & -.094 & -.072 \\
\hline Time/Време & .392 & -.564 & 1.347 & .804 & .422 & .020 & .019 \\
\hline Tense/Напетост & 1.846 & .629 & 3.062 & 2.977 & .003 & .102 & .071 \\
\hline Lonely/Усамљеност & -.559 & -1.766 & .648 & -.909 & .364 & -.035 & -.022 \\
\hline $\begin{array}{l}\text { Downhearted and de- } \\
\text { pressed/Депресивност }\end{array}$ & 1.091 & -.318 & 2.501 & 1.520 & .129 & .068 & .036 \\
\hline
\end{tabular}




\begin{tabular}{|c|c|c|c|c|c|c|c|}
\hline Exercise/Вежбање & -2.751 & -3.711 & -1.791 & -5.625 & .000 & -.169 & -.134 \\
\hline Religious/Религиозност & 1.143 & .022 & 2.263 & 2.001 & .046 & .051 & .048 \\
\hline $\begin{array}{c}\text { Social Exclusion/ Друштвена } \\
\text { искљученост }\end{array}$ & -2.409 & -3.934 & -.884 & -3.100 & .002 & -.106 & -.074 \\
\hline $\begin{array}{c}\text { Subjective urbanisation/ } \\
\text { Субјективна урбанизација }\end{array}$ & -2.789 & -4.938 & -.640 & -2.547 & .011 & -.065 & -.061 \\
\hline Education/Образовање & 3.476 & 1.402 & 5.550 & 3.290 & .001 & .089 & .078 \\
\hline $\begin{array}{c}\text { Unable tо work/ } \\
\text { Немогућност да се ради }\end{array}$ & 11.985 & -.449 & 24.419 & 1.892 & .059 & .047 & .045 \\
\hline $\begin{array}{c}\text { Unemploуеd/ Незапослен/ } \\
\text { незапослена }\end{array}$ & 4.833 & 2.210 & 7.457 & 3.615 & .000 & .094 & .086 \\
\hline $\begin{array}{c}\text { Divorced/ Разведен/ } \\
\text { разведена }\end{array}$ & 1.100 & -6.525 & 8.725 & .283 & .777 & .007 & .007 \\
\hline Widowed/Удовац/удовица & 2.251 & -1.645 & 6.147 & 1.134 & .257 & .031 & .027 \\
\hline
\end{tabular}

Table 4: Unstandardized Regression Coefficients for Gender and Age Groups/ Табела 4: Нестандардизовани коефицијенти регресије за полне и старосне категорије

\begin{tabular}{|c|c|c|c|c|c|c|}
\hline & \multicolumn{2}{|c|}{ Gender/Пол } & \multicolumn{4}{|c|}{ Age/Старост } \\
\hline & $\begin{array}{l}\text { Female/ } \\
\text { Жене }\end{array}$ & $\begin{array}{c}\text { Male/ } \\
\text { Мушкарци }\end{array}$ & $18-24$ & $25-44$ & $45-65$ & $65+$ \\
\hline Female/Женско & - & - & -3.39 & 2.085 & 1.632 & 0.007 \\
\hline Age/Старост & 0.032 & 0.091 & - & - & - & - \\
\hline $\begin{array}{l}\text { Subjective health/ } \\
\text { Субјективно } \\
\text { здравље } \\
\end{array}$ & $-4.334^{* * * *}$ & $-6.747^{* * * *}$ & -5.547 & $-4.958^{* * * *}$ & $-6.456^{* * *}$ & $-6.253^{* *}$ \\
\hline $\begin{array}{l}\text { Satisfaction with the } \\
\text { standard of living/ } \\
\text { Задовољство } \\
\text { животним } \\
\text { стандардом/ }\end{array}$ & 0.585 & 0.349 & $-1.925^{* *}$ & 0.699 & 0.701 & $2.411^{* * * *}$ \\
\hline $\begin{array}{l}\text { Satisfaction with } \\
\text { family life } \\
\text { Задовољство/ } \\
\text { породичним } \\
\text { животом } \\
\end{array}$ & 0.754 & $1.676^{* * *}$ & 2.307 & $1.685^{* *}$ & $1.166^{*}$ & 0.569 \\
\hline $\begin{array}{l}\text { Optimism about own } \\
\text { future/Оптимизам }\end{array}$ & $-2.948^{* *}$ & -1.317 & -4.298 & -1.116 & -1.576 & -2.388 \\
\hline $\begin{array}{c}\text { Worthwhile/ } \\
\text { Вредност }\end{array}$ & -0.74 & 0.09 & 1.247 & 0.588 & -1.717 & 1.77 \\
\hline
\end{tabular}




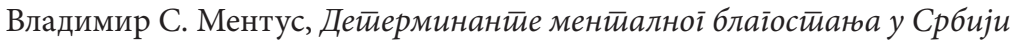

\begin{tabular}{|c|c|c|c|c|c|c|}
\hline Free/Слобода & -1.339 & $-3.003^{* *}$ & -2.662 & $-3.455^{* *}$ & -0.673 & 0.183 \\
\hline Time/Време & -0.25 & 1.334 & $4.52^{* *}$ & -1.181 & 1.38 & 1.393 \\
\hline Tense/Напетост & $3.198^{* * *}$ & 0.137 & 2.186 & 0.799 & $2.852^{* *}$ & -1.255 \\
\hline Lonely/Усамљеност & -0.139 & -0.523 & -4.73 & 0.592 & $-3.755^{* *}$ & 2.482 \\
\hline $\begin{array}{l}\text { Downhearted } \\
\text { and depressed/ } \\
\text { Депресивност }\end{array}$ & 0.781 & 1.084 & 4.263 & 0.818 & $2.588^{*}$ & 1.109 \\
\hline Exercise/Вежбање & $1.942^{*}$ & 0.388 & 1.252 & -0.231 & 1.239 & $3.449 *$ \\
\hline $\begin{array}{c}\text { Religious/ } \\
\text { Религиозност } \\
\end{array}$ & $-2.556^{* * *}$ & $-2.814^{* * *}$ & $-3.655^{*}$ & $-2.858^{* * *}$ & $-2.951 * *$ & 1.087 \\
\hline $\begin{array}{c}\text { Social Exclu- } \\
\text { sion/ Друштвена } \\
\text { искљученост }\end{array}$ & -1.937 & $-3.368^{* *}$ & $-6.795^{* *}$ & -0.347 & $-3.09 *$ & -1.872 \\
\hline $\begin{array}{c}\text { Subjective urbani- } \\
\text { sation/Субјективна } \\
\text { урбанизација }\end{array}$ & -2.957 & $-3.175^{*}$ & $-10.974^{* *}$ & $-4.88^{* *}$ & -0.52 & -0.513 \\
\hline $\begin{array}{c}\text { Education/ } \\
\text { Образовање }\end{array}$ & $3.979^{* *}$ & 2.722 & $11.102^{*}$ & 1.65 & 3.472 & 2.183 \\
\hline $\begin{array}{c}\text { Unable to work/ } \\
\text { Немогућност да се } \\
\text { ради } \\
\end{array}$ & 1.023 & $21.006^{* *}$ & - & 24.213 & 14.999 & -28.806 \\
\hline $\begin{array}{l}\text { Unemployed/ } \\
\text { Незапослен/ } \\
\text { незапослена }\end{array}$ & 3.278 & $6.057^{* *}$ & 2.164 & $7.074^{* *}$ & 3.873 & -4.654 \\
\hline $\begin{array}{c}\text { Divorced/ Разведен/ } \\
\text { разведена }\end{array}$ & -1.179 & 4.586 & 15.092 & 0.779 & -0.92 & 11.92 \\
\hline $\begin{array}{c}\text { Widowed/ Удовац/ } \\
\text { удовица }\end{array}$ & 2.084 & 5.512 & - & - & 1.402 & 3.918 \\
\hline
\end{tabular}

${ }^{*} p<.05 ; * * p<.01 ; * * * p<.001$ 
Table 5: Regression Results across Age and Gender Groups/

Табела 5: Резултати регресије за полне и старосне категорије

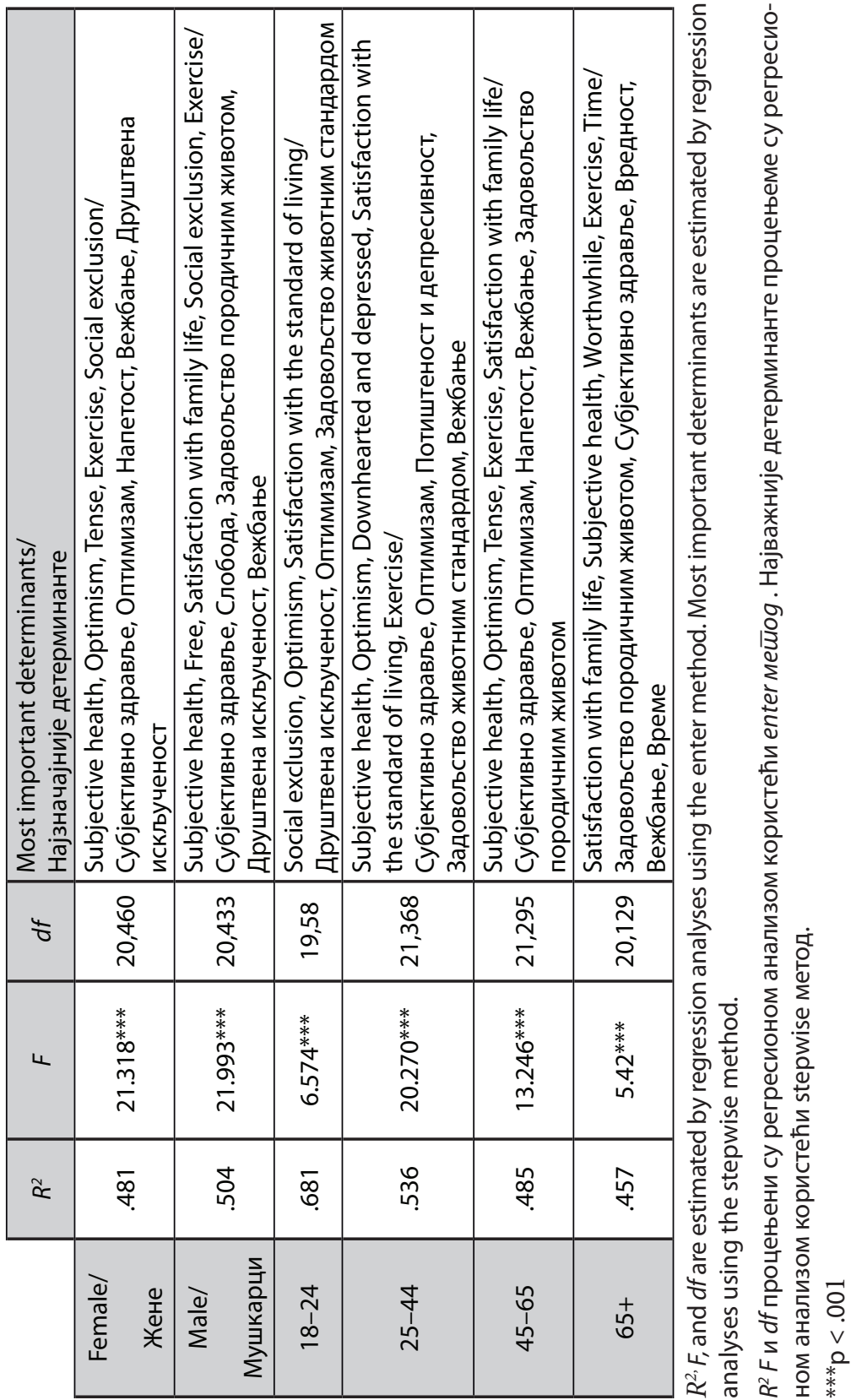

